\title{
A comparative Quantitative study on Momordin in the fruit and leave extracts of two different cultivars of Momordicacharantia Linn
}

\author{
Jobi Xavier ${ }^{1}$, Jayaram Reddy ${ }^{2}$ \\ ${ }^{1}$ Department of Botany, Bharathiar University, Coimbatore, India \\ ${ }^{2}$ Associate professor, St Joseph's College, Bengalruru, India
}

\begin{abstract}
Momordica charantia, is widely used as a medicinal plant. Studies have revealed that they contain an array of biologically active proteins like momordin which act as anti-tumor, anti-diabetic, and anti-rheumatic. Since momordin is an active compound, we have made a thorough study on the presence of momordin in the leave and fruit extracts of white and green varieties of the plant. Momordin eluted at 3.84-3.85 min under the standardized HPLC condition. It was found that the momordin was present only in the methanolic extracts of fruit and leave samples and not in the water extracts. The leave samples were found to be contained more quantity of momordin $(2878.57 \mu \mathrm{g} / \mathrm{mL})$ when compared with the fruit extract $(72.72 \mu \mathrm{g} / \mathrm{mL})$. It was also observed that green variety of bitter gourd contained more momordin than white varieties.
\end{abstract}

Keywords - Momordin, Charatin, HPLC, methanolic extract, Momordica Charantia.

\section{INTRODUCTION}

Momordica charantia Linn., belonging to the family Cucurbitaceae, is a widely cultivated plant for medicinal and food uses. The fruits of the plant are used for culinary preparations all over the world. The cooked fruits are eaten as a remedy for catarrh, eye and cough. The juice from the green fruit is drunk as a remedy for chronic colitis and dysentery ${ }^{1}$. The fruits of the plant are consumed regularly as food and medicine all over the world. The different phytochemical compounds present in the bitter gourd make it suitable for its medicinal use. It is widely used as a medicinal herb and the major bioactive compounds present in the plant are charatin, momordin, momordicineetc. The plants synthesize an array of metabolites characterized as 'phytoanticipins' or as general 'phytoprotectants" that are stored in specialized cellular compartments and released in response to specific environmental stimuli like damage due to herbivores, pathogens or nutrient depletion ${ }^{2}$.Bitter gourd also produces an array of secondary metabolites which show medicinal properties. The present study was an attempt to compare the quantity of the momordin present in the leaves and fruits of two cultivars (white and green fruited varieties) of Momordica charantia.

\section{MATERIALS AND METHODS}

Standard: Momordin $(1 \mathrm{mg} / \mathrm{mL})$. The standard stock was diluted to 100 and $200 \mu \mathrm{g} / \mathrm{mL}$ in HPLC grade methanol and used for HPLC analysis.

Samples:Bitter guard leaf and fruit aqueous and methanolic extracts (green and white varieties)

Sample preparation: Samples (1mL) were diluted with $4 \mathrm{~mL}$ respective solvent (water or methanol) and passed through $0.45 \mu$ membrane filter and analyzed by HPLC.

A gradient HPLC system with ODS C column 18 (250x 4.6mm) was used. The HPL Csystem was equipped with software. The mobile phase components were Acetonitrile (90\%): $0.0001 \%$ phosphoric acid in HPLC grade water (10). They were filtered through $0.2 \mathrm{~m}$ membrane filter before use and were pumped out the solvent reservoir at a flow rate $1 \mathrm{ml} / \mathrm{min}$. The Hamilton syringe was used for injecting $10 \mu \mathrm{L}$ of samples andeluted isocratically. The column temperature was maintained at $27^{\circ} \mathrm{C}$. The absorbance was measured at $215 \mathrm{~nm}$.

Momordin Quantification ( $\mu \mathrm{g} / \mathrm{mL}$ of extract): Momordin content in the sample quantified using the standard curve fit analysis of standard momordin response.

Linear regression equation obtained for momordin standard was used for quantification, $\mathrm{Y}=1.177 \mathrm{x}-7.575$, Where

$\mathrm{Y}=$ instrument response at $215 \mathrm{~nm}$ in $\mathrm{mV}$

$\mathrm{X}=$ Concentration of momordin in $\mu \mathrm{g} / \mathrm{mL}$.

\section{RESULTS}

The HPLC chromatogram of standard momordin is presented in Fig. 1 and Fig. 2. Momordin eluted at 3.843.85 min under the standardized HPLC condition. The summary of quantification of momordin content in samples 
are summarized in Table. 1. It was found that the momordin was present only in the methanolic extracts of fruit and leave samples and not in the water extracts. The leave samples were found to be contained more quantity of momordin $(2878.57 \mu \mathrm{g} / \mathbf{m L})$ when compared with the fruit extract $(72.72 \boldsymbol{\mu g} / \mathbf{m L})$. It was also observed that green variety of bitter gourd contained more momordin than white varieties.

Table.1: HPLC summary report.

\begin{tabular}{|c|c|c|c|c|c|}
\hline $\begin{array}{l}\text { Sl. } \\
\text { No }\end{array}$ & Sample Code & $\begin{array}{c}\text { Retention } \\
\text { Time } \\
\text { (min) }\end{array}$ & Peak Area & $\begin{array}{c}\text { Momordin } \\
\text { Content }(\mu g / m L)\end{array}$ & $\begin{array}{l}\text { Chromatogram } \\
\text { reference }\end{array}$ \\
\hline 1 & Momordin $(100 \mu \mathrm{g} / \mathrm{mL})$ & 3.840 & 97.574 & & Fig.1 \\
\hline 2 & Momordin $(250 \mu \mathrm{g} / \mathrm{mL})$ & 3.850 & 291.903 & - & Fig. 2 \\
\hline 3 & $\begin{array}{c}\text { Bitterguard_Whitefruit_methanolic } \\
\text { extract }\end{array}$ & 3.8 & 9.54 & 72.71 & Fig. 3 \\
\hline 4 & Bitterguard_Whitefruit_Aquous & - & - & - & Fig.4 \\
\hline 5 & $\begin{array}{l}\text { Bitter guard_White Leaf_ } \\
\text { methanolic extract }\end{array}$ & 3.8 & 542.98 & 2338.81 & Fig.5 \\
\hline 6 & Bitterguard_WhiteLeaf_Aquous & - & - & - & Fig. 6 \\
\hline 7 & $\begin{array}{l}\text { Bitter guard_Green fruit_ } \\
\text { methanolic extract }\end{array}$ & 3.87 & 0.71 & 35.19 & Fig. 7 \\
\hline 8 & $\begin{array}{c}\text { Bitter guard_Green Leaf_ } \\
\text { methanolic extract }\end{array}$ & 3.87 & 670.04 & 2878.57 & Fig. 8 \\
\hline 9 & Bitterguard_Greenfruit_Aquous & 3.8 & 5.76 & 56.65 & Fig. 9 \\
\hline 10 & Bitterguard_GreenLeaf_Aquous & - & - & - & Fig. 10 \\
\hline
\end{tabular}

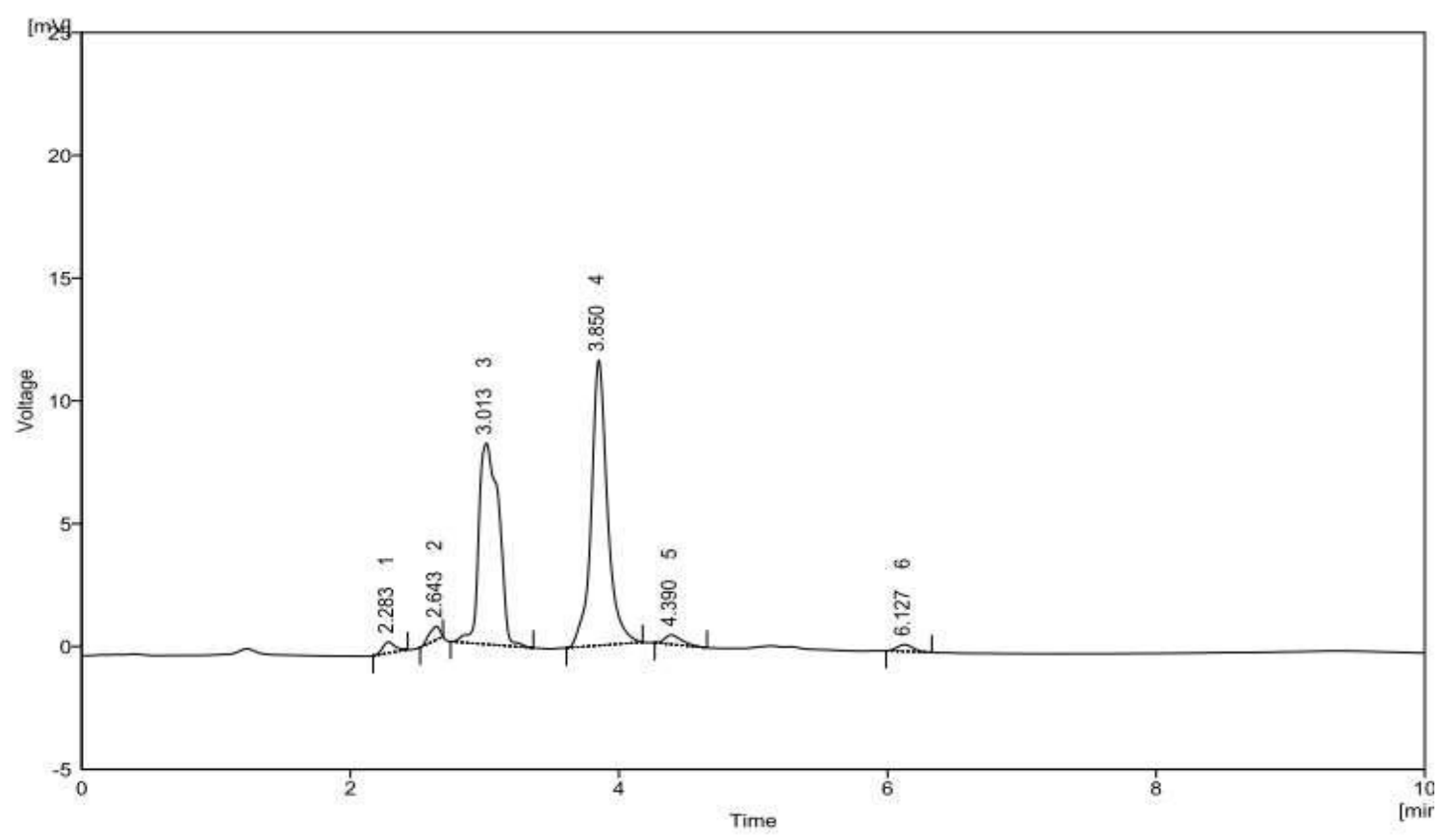

Fig.1: HPLC chromatogram of momordin $(100 \mu \mathrm{g} / \mathrm{mL})$ 


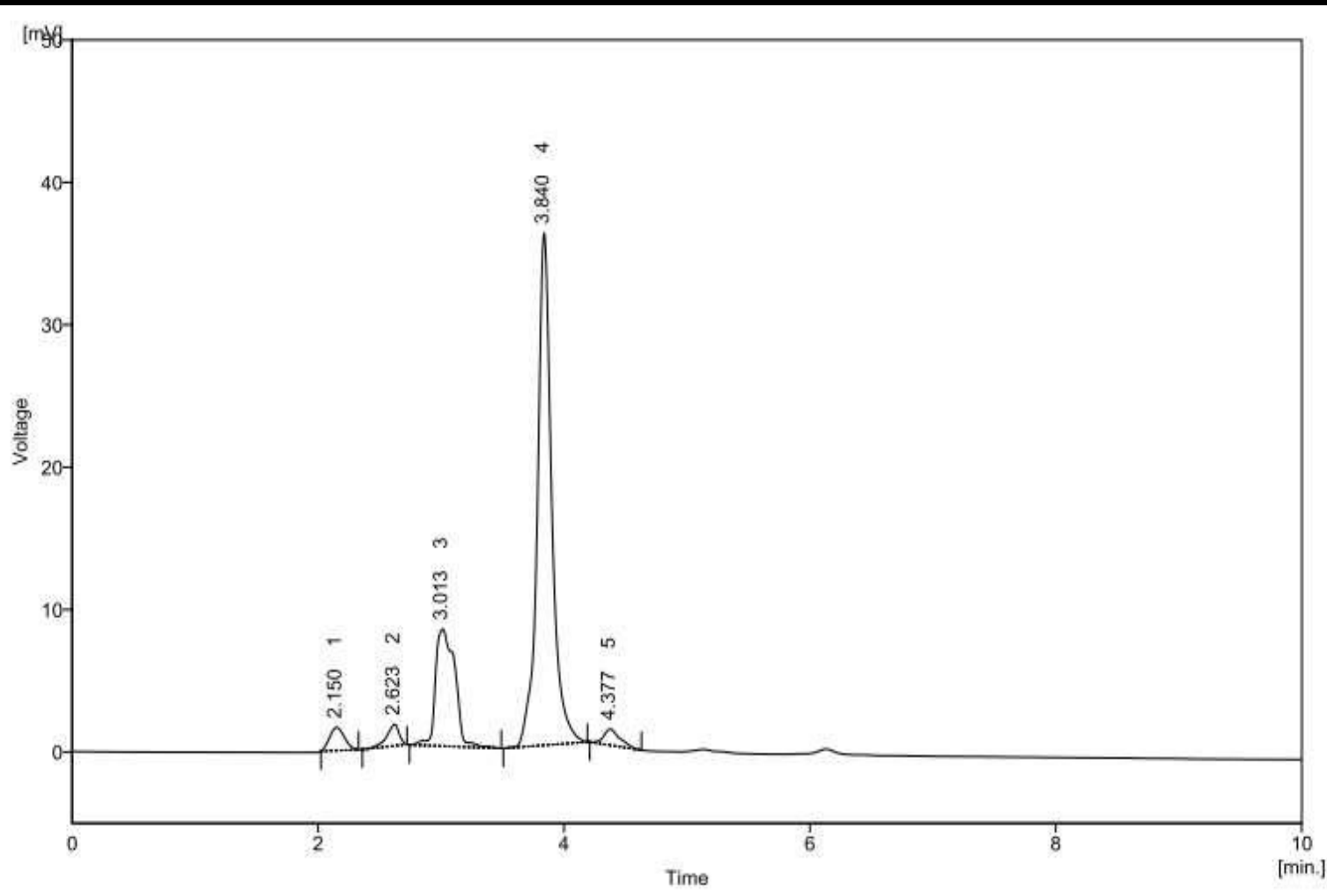

Fig.2: HPLC chromatogram of Momordin $(250 \mu \mathrm{g} / \mathrm{mL})$

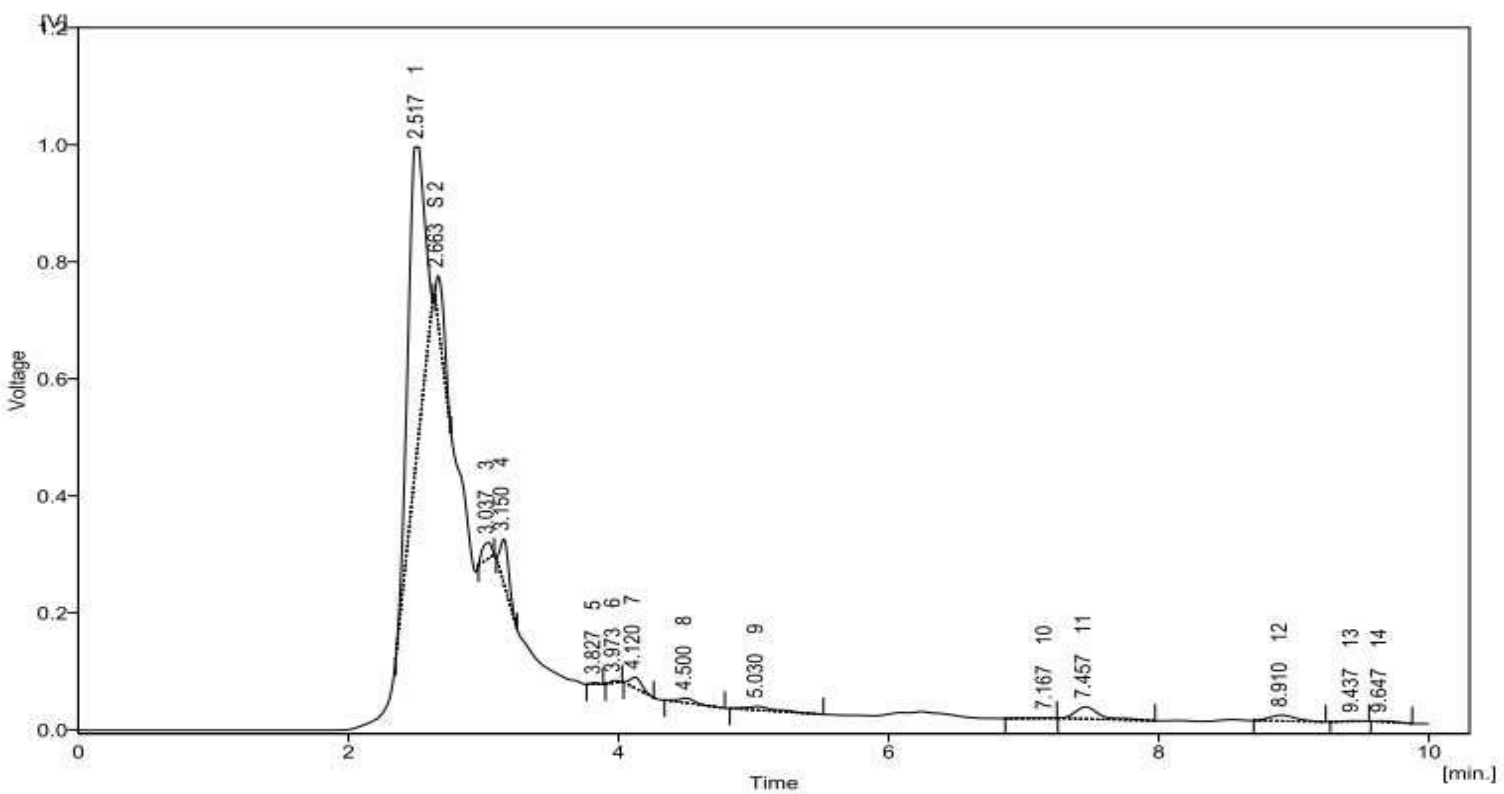

Fig.3: HPLC chromatogram of Bitter guard_White fruit_methanol (1:5 diln) 


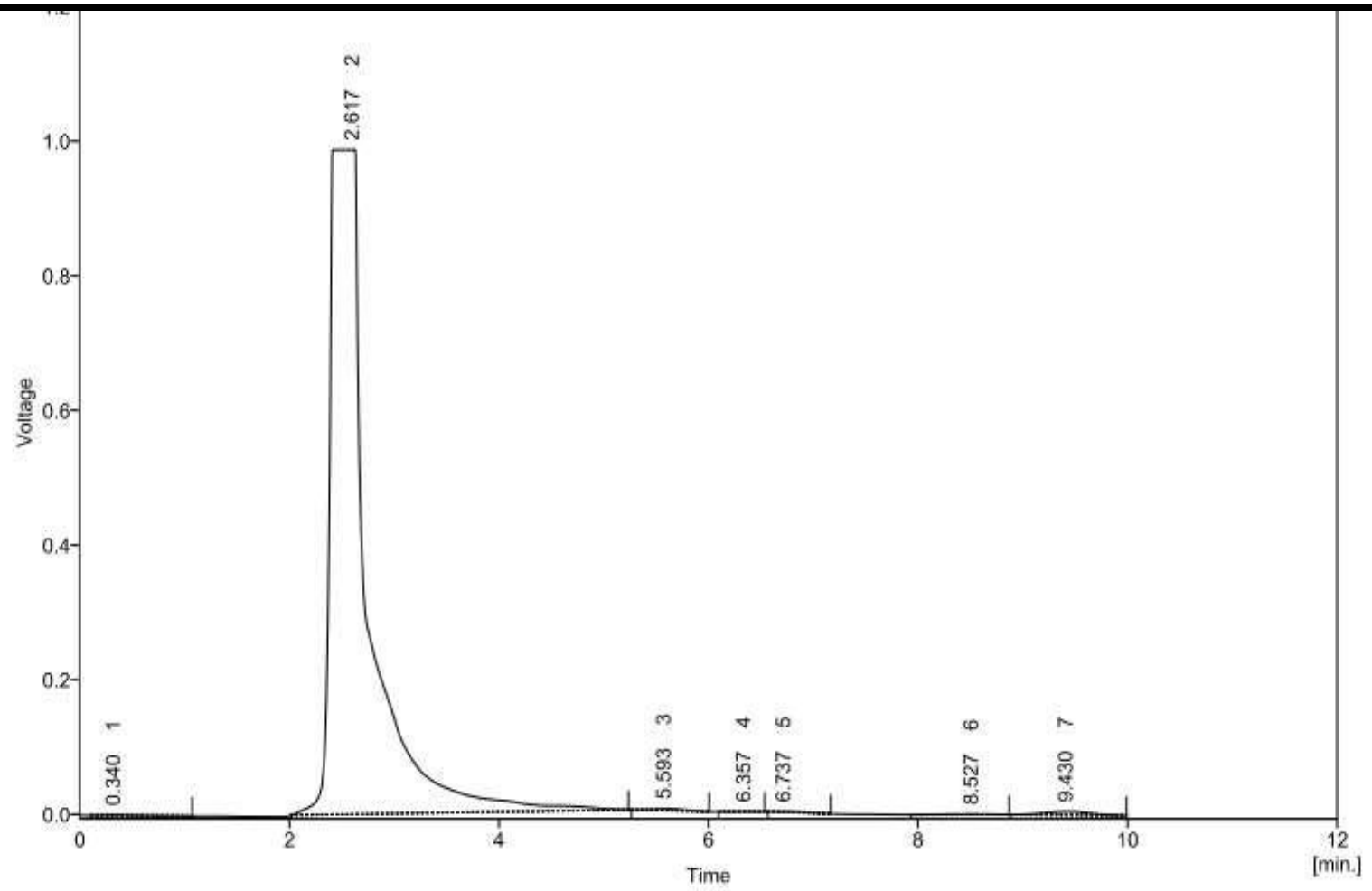

Fig.4: HPLC chromatogram of Bitter guard_Whitefruit_Aq (1:5 diln)

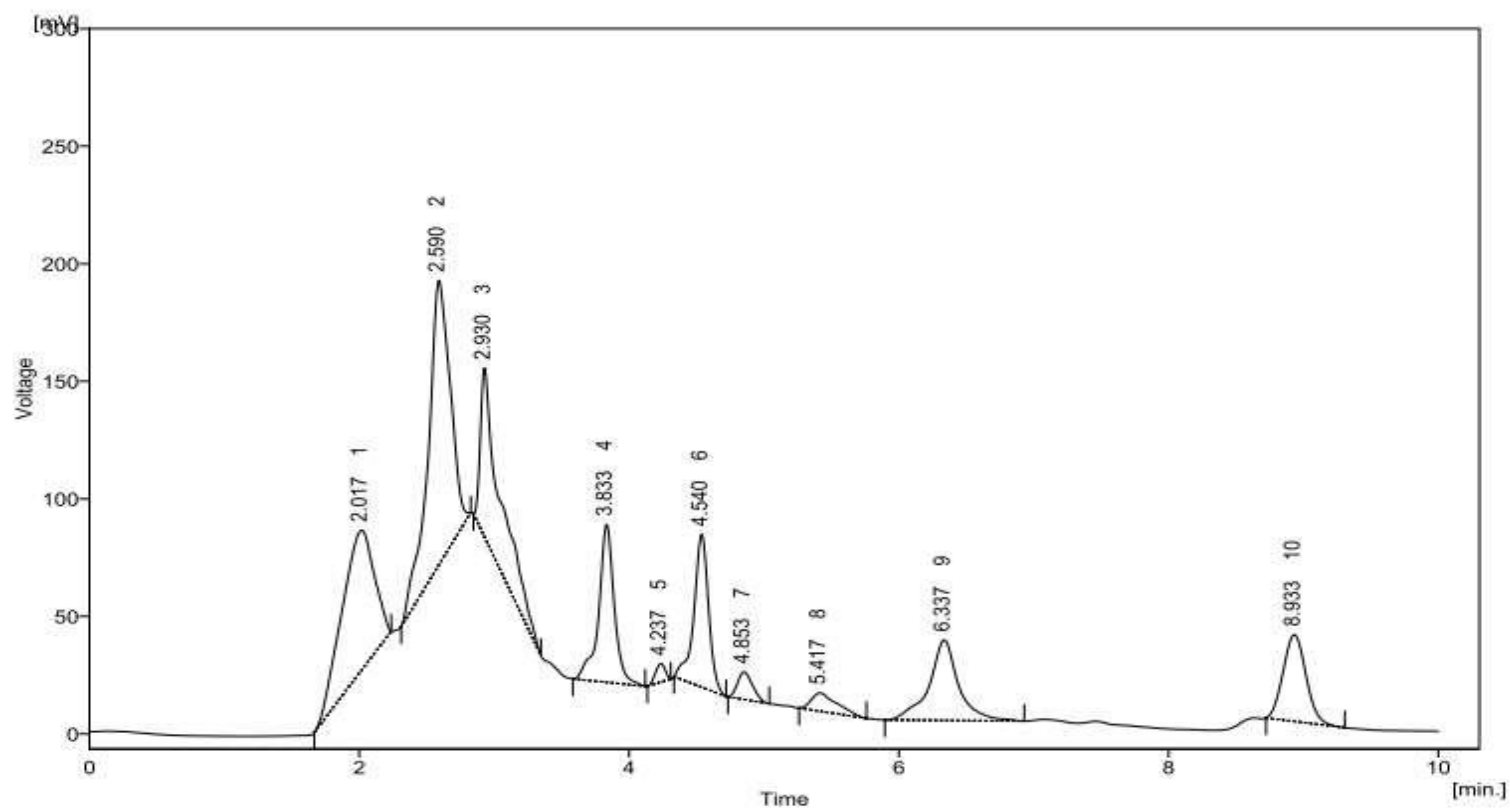

Fig.5: HPLC chromatogram of Bitter guard_White Leaf_methanol (1:5 diln) 


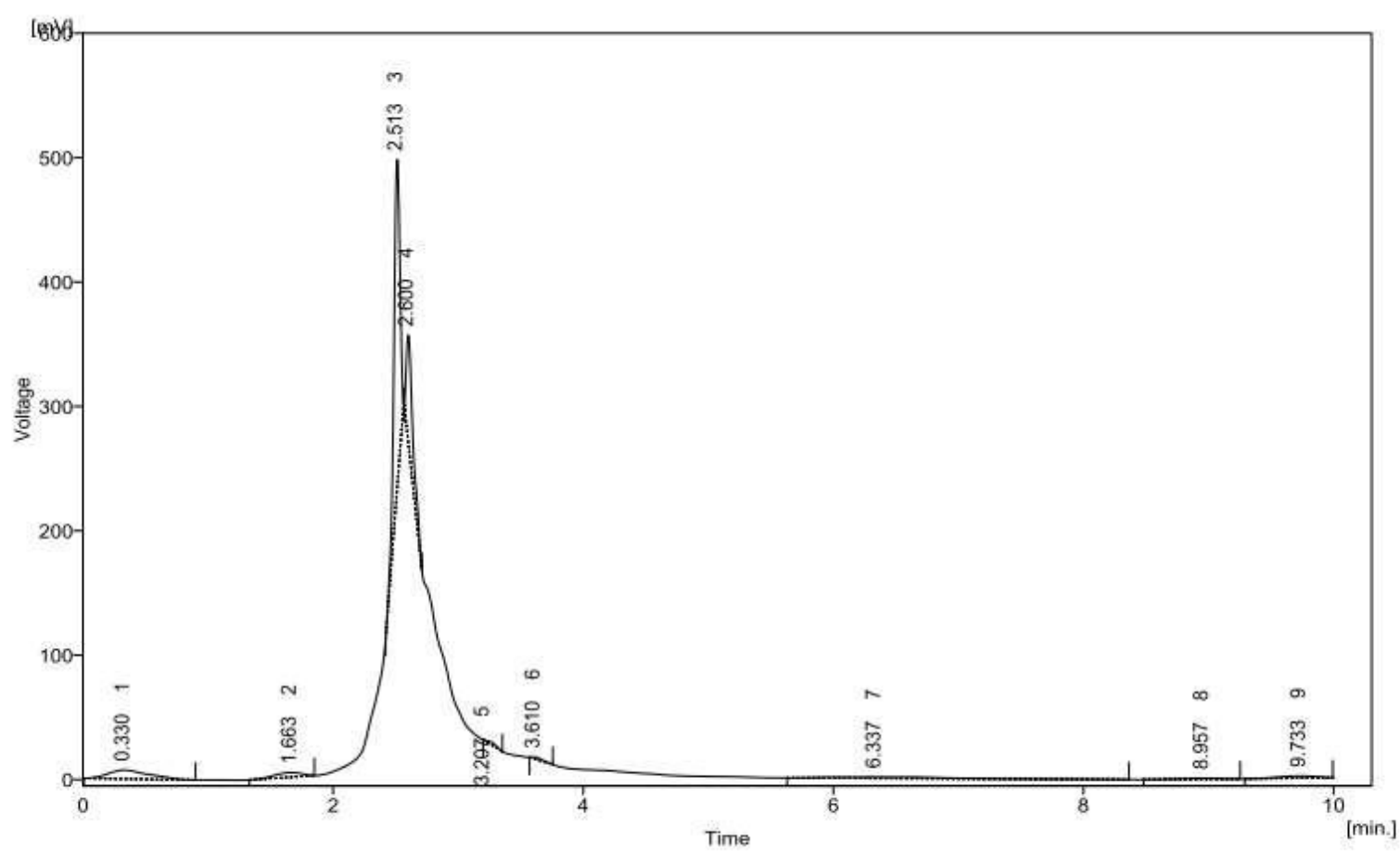

Fig.6: HPLC chromatogram of Bitter guard_WhiteLeaf_Aq (1:5 diln)

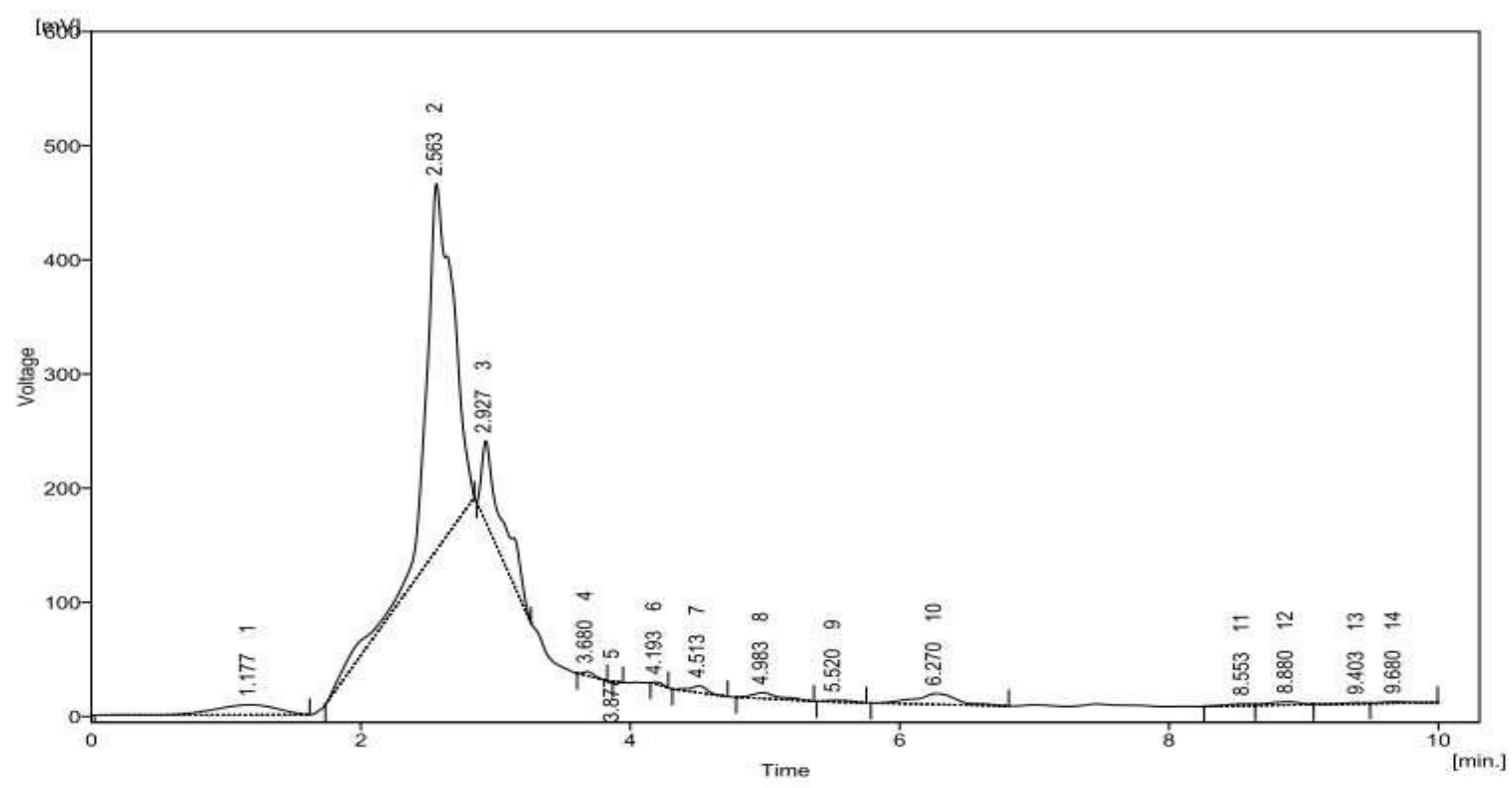

Fig.7: HPLC chromatogram of B Bitter guard_Green fruit_methanol (1:5 diln) 


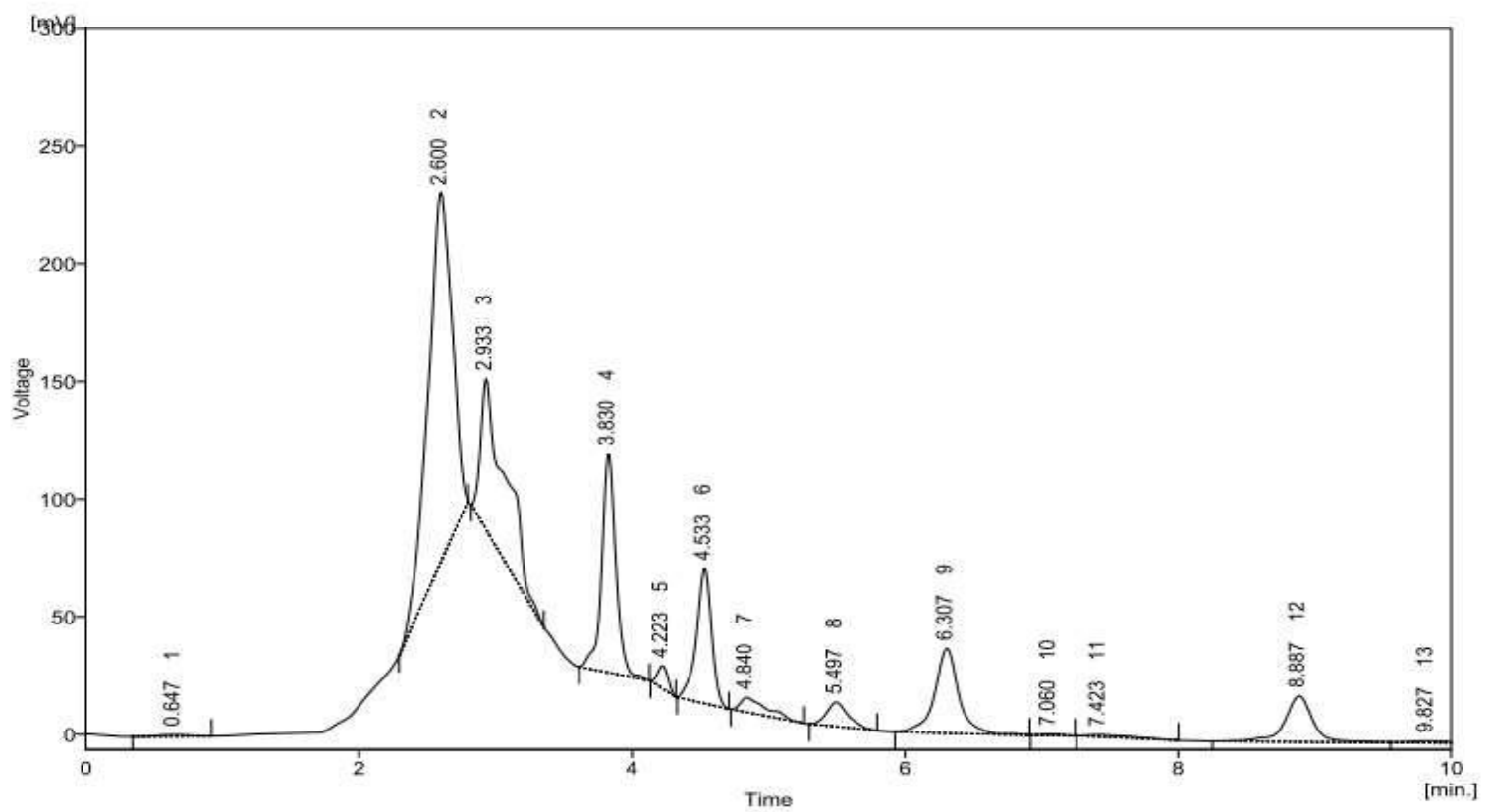

Fig.8: HPLC chromatogram of Bitter guard_GreenLeaf_methanol (1:5 diln)

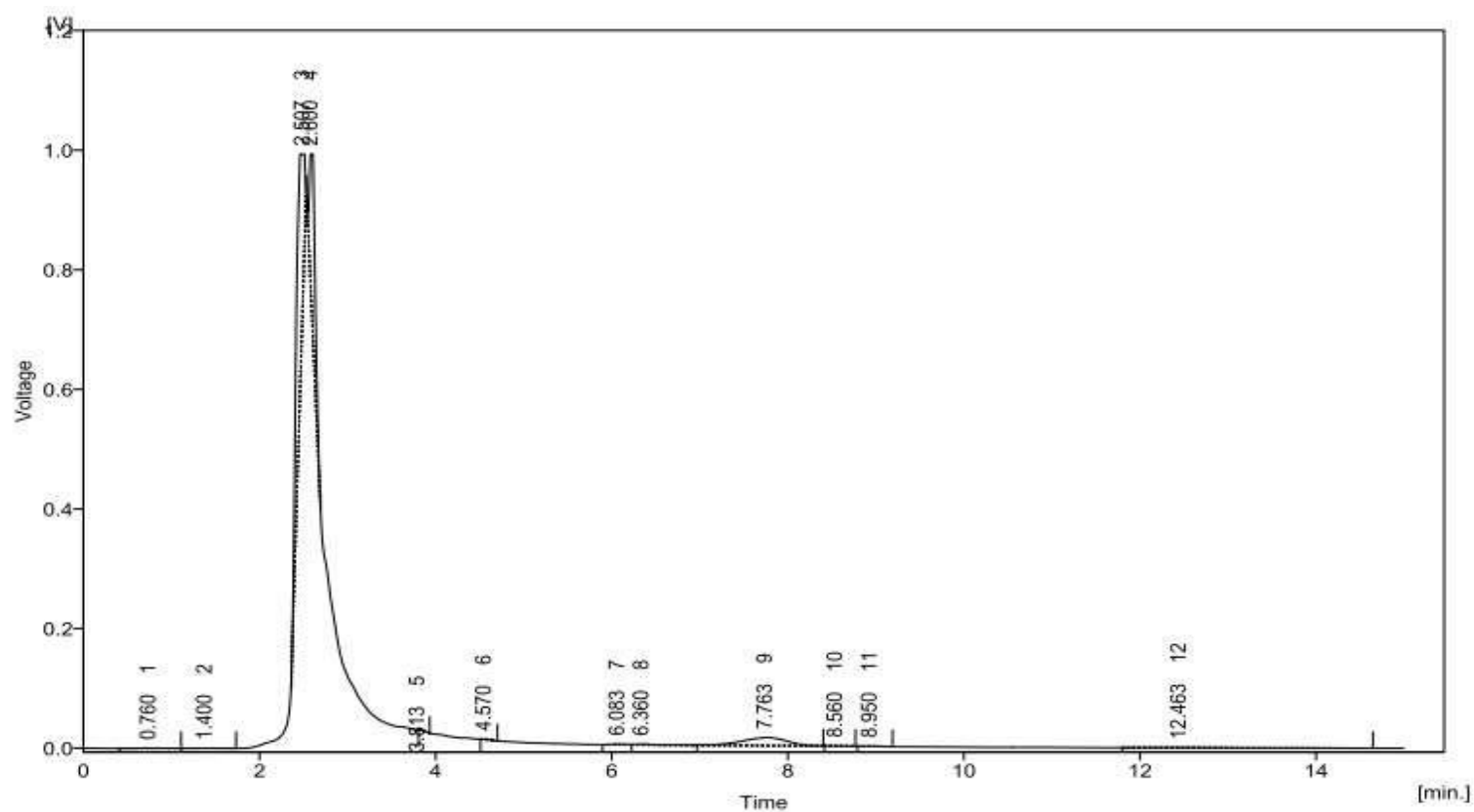

Fig.9: HPLC chromatogram of Bitter guard_Greenfruit_Aq (1:5 diln) 


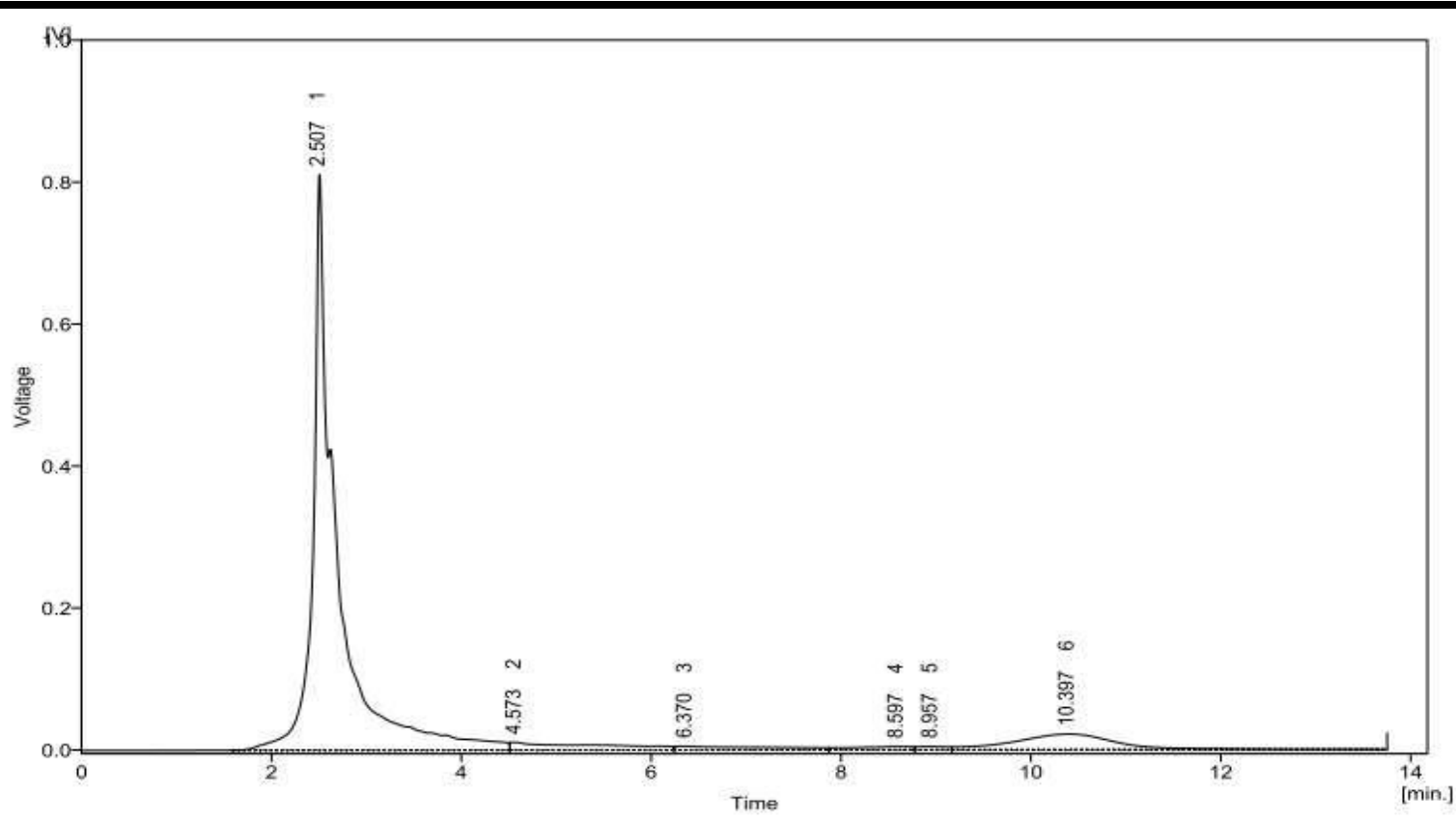

Fig.10: HPLC chromatogram of Bitter guard_GreenLeaf_Aq (1:5 diln)

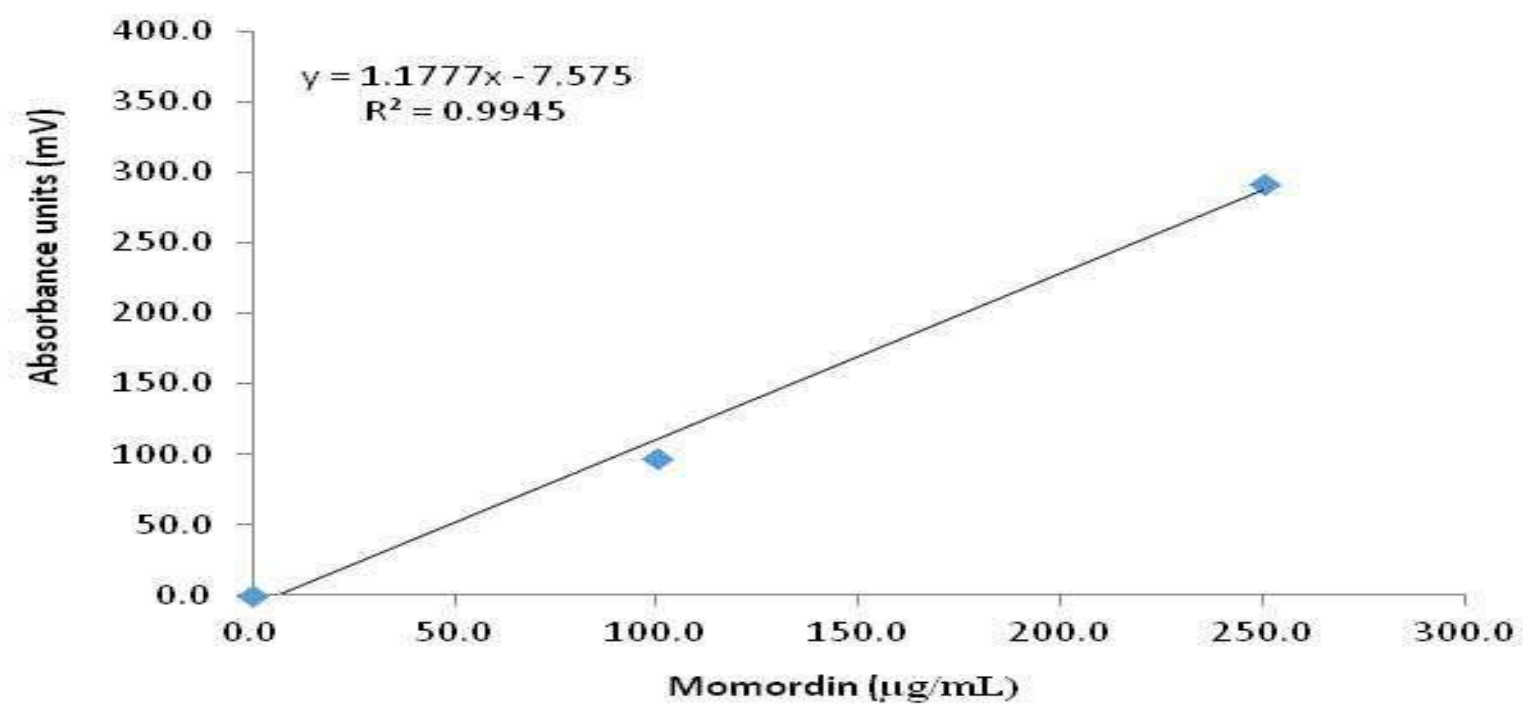

Fig.11: Standard graph of momordin

\section{DISCUSSION}

Momordica charantia, widely used as a medicinal plant contains many phytochemical compounds. Many studies have proved that bioactive compounds present in the plant are responsible for the high medicinal value. Studies have revealed that they contain an array of biologically active proteins, namely, momordin, a- and b-momorcharin, cucurbitacin, and MAP30, that have shown to have highly effective anti-human immunodeficiency (HIV), anti-tumor anti-diabetic, and anti-rheumatic properties and to function as febrifuge medicine for jaundice, hepatitis, leprosy, hemorrhoids, psoriasis, snakebite, and vaginal discharge ${ }^{3}$. Since momordin is an active compound, we have made a thorough study on the presence of momordin in the leave 
and fruit extracts of white and green varieties of the plant.

The present study revealed that momordin is high in the leave extracts compared to fruit extracts.

\section{CONCLUSION}

The study revealed the fact that the leave extracts of the plant Momordica charantia contains more quantity of momordin, one of the several saponins derived from oleanolic acid, a triterpenoid. Leaves can be more useful than fruit in terms of its medicinal value.

\section{ACKNOWLEDGMENT}

I am grateful to all my professors and lab attenders who helped me in completing this paper.

\section{REFERENCES}

[1] Kuri E. Yuwai et al., "Chemical composition of Momordica charantia L. fruits", J. Agric. Food Chem., 1991, 39 (10), pp 1762-1763.

[2] Kennedy DO, Wightman EL. Herbal extracts and phytochemicals: plant secondary metabolites and the enhancement of human brain function. Advances in Nutrition 2011; 2: 32-50.

[3] Prarthna Daniel, UjjwalaSupe, M.G.Roymon "A review on Phytochemical analysis of Momordica charantia",International Journal of Advances In Pharmacy, Biology And Chemistry (IJAPBC), Vol. 3(1), Jan - Mar, 2014. 